\title{
HYDROGEN PRODUCTION - AN ENVIRONMENTAL ISSUE
}

\author{
Lília Fernanda Cardoso Souzal \\ Natália de Mello Esteves ${ }^{2}$ \\ João Paulo Covre ${ }^{3}$ \\ Rosenir Rita de Cassia Moreira da Silva ${ }^{4}$
}

\begin{abstract}
A growing interest in hydrogen use has been observed due to its environmentally friendly characteristics. However, the current methods of hydrogen production from natural gas are based on steam methane reforming, partial oxidation, and autothermal reforming. These processes produce a mixture of hydrogen and carbon oxides and after water-gas shift reactions, in order to increase the production of hydrogen, a large amount of $\mathrm{CO}_{2}$ is generated and possibly released in the atmosphere. In this context, the catalytic methane decomposition has been receiving attention as an alternative route to the production of $\mathrm{CO}_{\mathrm{x}}$-free hydrogen. It has been reported that the appropriate group of catalysts and reactors can lead to a viable process. Current investigations attempt to increase the yield of hydrogen. The present work aims to evaluate the processes currently used for that and to present the preliminary results obtained with cobalt catalysts for methane decomposition. A comparison between the conventional processes and the suggested ones is made, and the major advantages in the use of methane decomposition are presented.
\end{abstract}

Keywords: Hydrogen production, clean technology, methane decomposition.

\section{INTRODUCTION}

Hydrogen has been considered one of the most promising energy carriers due to its environmentally friendly characteristics. It could be used in fuel cells, capable of converting chemical energy into electricity and heat without generating greenhouse gas. The reaction that occurs then is the oxidation of $\mathrm{H}_{2}$ in order to produce water, which makes the procedure ideal for use as automotive fuel. A growing interest in researching new technologies for the development of safe and effective processes for hydrogen production on a large scale has been observed. The general aim is to allow the use of hydrogen as a clean energy source.

Currently, hydrogen production derives from synthesis gas, a mixture of carbon monoxide (CO) and hydrogen $\left(\mathrm{H}_{2}\right)$, produced from fossil fuels, particularly natural gas. Traditionally, the used processes are: steam reforming of methane, partial oxidation, and auto-thermal reforming (the two previous reactions combined).

The main issue is that those procedures, when performed in industries, also generate a massive amount of $\mathrm{CO}_{2}$, which could be released in the environment. In the United States of America, it is estimated that $13.7 \mathrm{~kg}$ of $\mathrm{CO}_{2}$ are produced for every $1 \mathrm{~kg}$ of $\mathrm{H}_{2}$ in the process of steam reforming (Muradov and Veziroglu, 2008). Therefore, what happens is the change of polluting gases emission from cars to industries.

Nowadays, the production of $\mathrm{CO}_{2}$ is a very controversial issue due to problems related to global warming and its severe environmental consequences. According to the International Energy Agency (IEA), in 2005, global $\mathrm{CO}_{2}$ emission

\footnotetext{
1 Chemical Engineering Department, Universidade Federal Fluminense, Brazil. e-mail: life375@hotmail.com

2 Chemical Engineering Department, Universidade Federal Fluminense, Brazil. e-mail: nataliademelloesteves@hotmail.com

3 Chemical Engineering Department, Universidade Federal Fluminense, Brazil. e-mail: joaopmc@hotmail.com

${ }^{4}$ Chemical Engineering Department, Universidade Federal Fluminense, Brazil. e-mail: rosenir@vm.uff.br
} 
related to energy supply reached $27.7 \mathrm{Gt}$ - from coal $(11.1 \mathrm{Gt})$, oil $(11 \mathrm{Gt})$, and gas $(5.6 \mathrm{Gt})$. If measures are not taken, the total amount can rise to $42 \mathrm{Gt}$. by 2030. According to Bradford and Beaubien (2008), thermoelectric power generation in the USA produces the largest amount of pollution in the world - 39\% of industrial emissions of $\mathrm{CO}_{2}-$, followed by transportation (33\%) and, finally, industry (27\%). The high emission of $\mathrm{CO}_{2}$ from cars is a big challenge to be overcome, since we face difficulties related to the type of fuel that must be used in vehicles.

Studies have been analyzing several other processes for hydrogen generation from biomass, primarily through steam reforming, gasification, and bio-oils pyrolysis. According to Tanksale et al. (2010), although those procedures also generate $\mathrm{CO}$ and $\mathrm{CO}_{2}$, they are considered neutral because the gas produced might be used in the later generation of biomass, which is a renewable energy source.

Nevertheless, it is estimated that natural gas will continue to be used in large scales in the future due to its large sources in the world and to the established industrial market related to it. According to Abbas e Daud (2010), the problems of establishing processes based on renewable sources are the low energy efficiency and the high cost, especially in the case of biomass. The authors report that the spelling price of hydrogen produced from renewable sources is about US\$1,21-2,42/ $\mathrm{Kg}$, with energy efficiency at about $40-50 \%$, whereas the spelling price of hydrogen produced from natural gas is about US $\$ 0,75 / \mathrm{Kg}$ for steam reforming, US $\$ 0,98 / \mathrm{Kg}$ for partial oxidation, and US $\$ 1,93 / \mathrm{Kg}$ for auto-thermal reforming.

Using natural gas, the production of $\mathrm{CO}_{x}-$ free hydrogen can only be made through catalytic methane decomposition (Muradov and Verziglu, 2008),. The authors also show that Universal Oil Products (UOP) operated a pilot plant in the 1960s with capacity for the continuous production of $118 \mathrm{~L} / \mathrm{min}$ of hydrogen in moving bed reactors using $\mathrm{Ni}$ catalysts; later, however, when oil became largely available, the plant was abandoned. For those authors, the proper selection of catalysts and reactors for the decomposition of methane with continuous catalyst regeneration can lead to a viable process for hydrogen production. One of the major challenges of this alternative is developing active catalysts that might be easily regenerated (that is, catalysts that operate for several reactions/regeneration cycles).

Studies are being developed in our RECAT/ UFF Laboratory (SILVA, 2008; DOURADO, 2007; GUARINO, 2005) with the use of Co catalysts supported on silica and alumina in the methane decomposition reaction. Deactivation tests with catalyst regeneration through steam water were performed and the results are promising. The viability of this process might lead to pure hydrogen production, which is an environmentally attractive alternative.

The objective of the present work is to compare currently employed processes for the production of hydrogen and to present the preliminary results obtained with Co catalysts for methane decomposition. The tests with catalysts were performed in our laboratory. This work also presents the main advantages of using this process for hydrogen generation.

\section{PROCESSES CURRENTLY EMPLOYED FOR GENERATING STREAMS THAT ARE RICH IN HYDROGEN FROM NATURAL GAS, WITH CONCOMITANT PRODUCTION OF $\mathrm{CO}_{2}$}

\subsection{STEAM REFORMING OF NATURAL GAS}

The process of steam reforming of natural gas is the reaction of methane with water at around $700^{\circ} \mathrm{C}$ in the presence of supported $\mathrm{Ni}$ catalysts in order to produce a mixture of $\mathrm{CO}$ and $\mathrm{H}_{2}$. The strongly endothermic reaction can be represented as in (1).

$$
\begin{aligned}
& \mathrm{CH}_{4}+\mathrm{H}_{2} \mathrm{O} \rightarrow \mathrm{CO}+3 \mathrm{H}_{2} \\
& \Delta \mathrm{H}_{298 \mathrm{~K}}=+206 \mathrm{~kJ} / \mathrm{mol}
\end{aligned}
$$

However, hydrogen production needs the water-gas shift reaction, represented by (2), in which more hydrogen would be formed and $\mathrm{CO}$ would be converted into $\mathrm{CO}_{2}$. This catalytic reaction takes place in two stages: one in high temperature, at around $350^{\circ} \mathrm{C}(\mathrm{HTR}$ - high temperature reaction), using a catalyst based on iron oxide; another one in low temperature, at around $200^{\circ} \mathrm{C}$ (LTR - low temperature reaction), using catalysts based on copper oxide. 
$\mathrm{CO}+\mathrm{H}_{2} \mathrm{O} \rightarrow \mathrm{CO}_{2}+\mathrm{H}_{2}$

$\Delta \mathrm{H}_{298 \mathrm{~K}}=-41 \mathrm{~kJ} / \mathrm{mol}$

In general, this process is viable when associated with methanol synthesis. The entire amount of methanol is produced from steam reforming of natural gas. This process does not need the watergas shift reaction, and the $\mathrm{CO}-\mathrm{CO}_{2}$ molecules produced are converted into methanol. A simplified scheme of methanol production is presented in Figure 1.

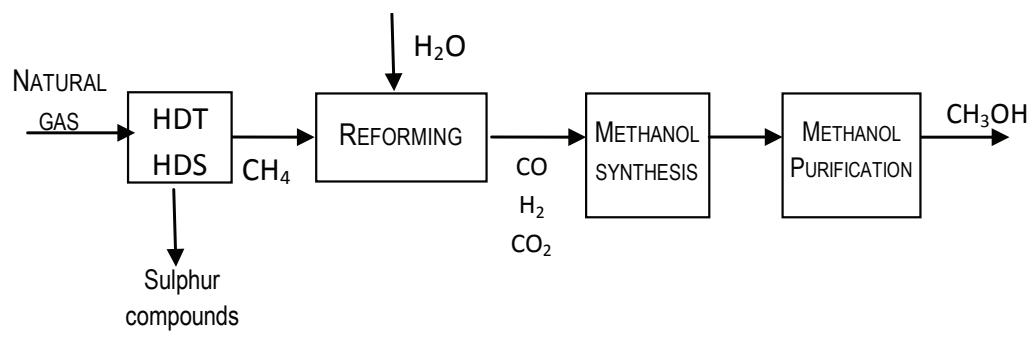

Figure 1 - Simplified scheme of methanol production

\subsection{PARTIAL OXIDATION OF NATURAL} GAS

This process involves the catalytic partial oxidation of methane in order to produce synthesis gas. The exothermic reaction can be represented by (3). The problem is that this reaction must be well managed, or it can lead to total oxidation, producing $\mathrm{CO}_{2}$ and water.

$\mathrm{CH}_{4}+1 / 2 \mathrm{O}_{2} \rightarrow \mathrm{CO}+2 \mathrm{H}_{2}$

$\Delta \mathrm{H}_{298 \mathrm{~K}}=-36 \mathrm{~kJ} / \mathrm{mol}$

Currently, this reaction is coupled with steam methane reforming to constitute the auto-thermal reforming process.

\subsection{AUTO-THERMAL REFORMING}

This process consists in the association of two previous processes: steam reforming and partial oxidation. The first process is an endothermic reaction, while the second one is an exothermic one, leading to desirable global levels of energetic balance. The product is the synthesis gas. In order to generate $\mathrm{CO}_{\mathrm{x}}$-free hydrogen, this process requires both water-gas shift reaction steps (HTR and LTR) and subsequent absorption of the $\mathrm{CO}_{2}$ produced. Using the hydrogen obtained in this process for fuel cells is expensive because the membrane cells require high purity hydrogen due to its easy poisoning by $\mathrm{CO}$ gas.

This process is often used in ammonia production, taking natural gas, steam water and air as feedstock. The two steps of the water-gas shift reaction, the low and the high temperature ones, need to occur in order to completely convert the reactants into $\mathrm{H}_{2}$ and $\mathrm{CO}_{2}$. The introduction of air in the primary reformer allows that, after several catalytic stages and absorption of $\mathrm{CO}_{2}$, the reaction mixture reaches the reactor for ammonia synthesis in the correct ratio of three molecules of $\mathrm{H}_{2}$ for one molecule of $\mathrm{N}_{2}$. All catalytic steps of the process are made in specific reactors, using different catalysts and different operational conditions. Figure 2 shows a simplified scheme of the process of ammonia production.

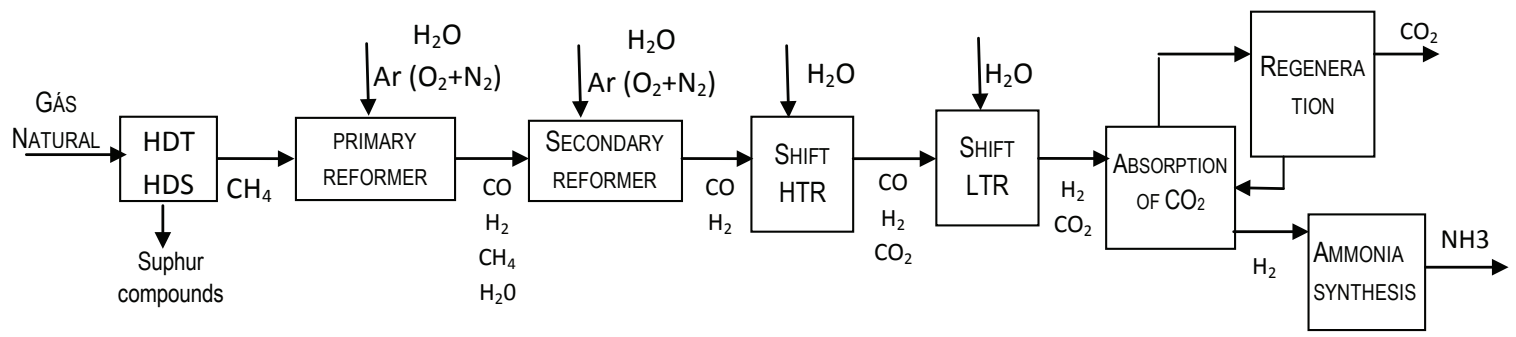

Figure 2 - Simplified scheme of ammonia production 


\section{METHANE DECOMPOSITION}

A promising alternative for the direct production of pure hydrogen in the gas phase would be the direct catalytic decomposition of methane. For each molecule of methane, two hydrogen molecules are formed. The reaction is moderately endothermic, produces hydrogen and coal deposits on the catalyst surface, and can be represented by reaction (4).

$$
\mathrm{CH}_{4} \rightarrow \mathrm{C}+2 \mathrm{H}_{2}
$$

$\Delta \mathrm{H}_{298 \mathrm{~K}}=74,52 \mathrm{~kJ} / \mathrm{mol}$

The second reaction product, obtained in solid form, is characterized by carbon deposits that, depending on reaction conditions and on the metallic particle size of the catalyst, can be constituted of carbon nanotubes (which are interesting for industries), or carbon filaments (which would promote the deactivation). There are many researches that also suggest the possibility of using carbon in manufacturing car tires, rubber, plastic, and ink (MURADOV, 1998).

Other studies suggest the integration of processes in the attempt to make hydrogen production more viable by lowering costs with catalysts and by eliminating the emission of pollutant gases. This process could use fluidized bed reactors for hydrogen production with continuous catalyst regeneration, which is similar to the fluidized catalytic-cracking process currently used in many refineries (MURADOV, 2005). Figure 3 shows an example of integrated hydrogen process with methanol synthesis in different synthesis reactors, eliminating secondary purification steps.

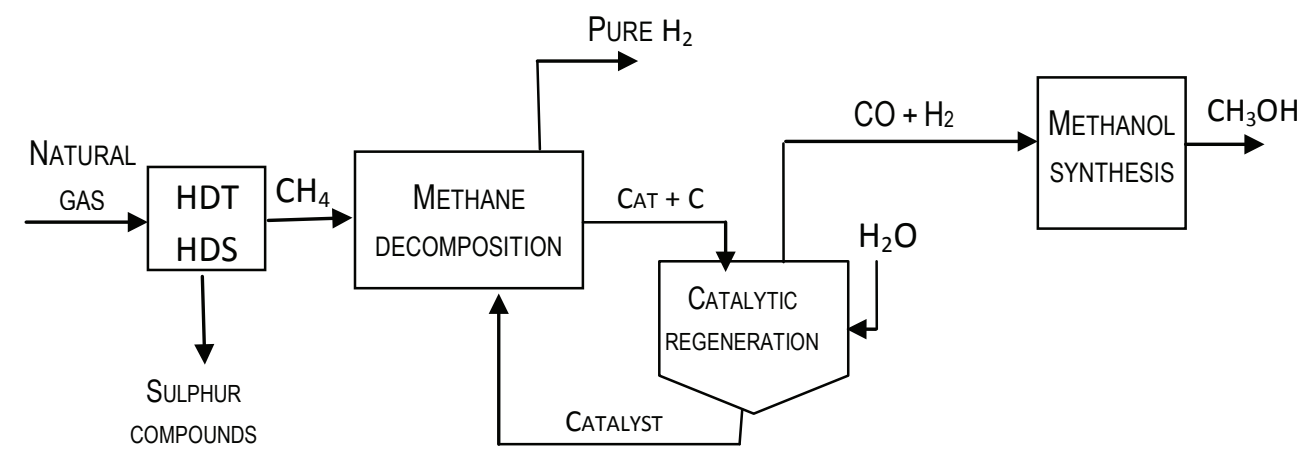

Figure 3 - Simplified scheme for the integrated production of $\mathrm{H}_{2}$ and methanol

Depending on the reasons why hydrogen is being used, several alternatives can be adopted for methane decomposition process. In general, this process offers advantages over conventional processes, such as the ones listed below:

- Smaller units. This process would not require large amounts of air, as the autothermal reforming does.

- It would need smaller equipments and reactors, using compact units.

- By integrating the plants, a portion of the energy needed for the decomposition of methane could be supplied by the methanol synthesis, which generates heat.

- It would be more simplified process with less catalytic reactions using different catalysts.
- The pure hydrogen produced in the first step could be used in fuel cells and in the production of ammonia.

- This process is performed in one step. Therefore, it does not require reactors for the water-gas shift reaction.

- In Brazil, the integration of processes would reduce the importation of methanol, which, in 2008, reached approximately 250.000 tons, equivalent to $50 \%$ of total consumption.

- In the case of using the hydrogenammonia integrated process, the costs could be minimized and the market would have a better offer of ammonia, whose importation reached 300.000 tons in 2008. 
- Finally, this process could produce hydrogen for automobiles with fuel cells.

\section{VEHICLES WITH FUEL CELLS}

The major interest in the use of hydrogen as a fuel is related to environmental issues. Several publications describe the dramatic increase in the concentrations of carbon dioxide, methane, nitrous e sulfur oxides in the atmosphere, especially in metropolises. An elevated number of automobiles operating with gasoline and diesel are responsible for this scenario. In the case of heavy vehicles fueled by diesel, which has an elevated content of sulfur compounds, the use of automotive catalysts is still restricted. The use of natural gas still represents an important improvement in the reduction of pollutant gases, but zero emission is only possible with hydrogen.

In the engines functioning with fuel cells, hydrogen and air react and form water through electrochemical reaction, producing electricity. A single product is formed, without contaminated gases. Hydrogen supply should be produced in fuel stations or in bus garages. In Brazil, some projects related to fuel cells buses have already been published, mainly in São Paulo and Rio de Janeiro. The Federal University of Rio de Janeiro (UFRJ) has a hydrogen-fueled bus that circulates inside the campus.

Therefore, several studies under development aim to debate hydrogen production in accordance with the necessities and limitations imposed by the operation of plants in urban centers. Smaller units are required in most case. The source should be natural gas, which is already available for distribution in big cities through gas pipelines.

\section{CATALYSTS USED IN THE DECOMPOSITION OF METHANE FOR HYDROGEN PRODUCTION}

An important issue in hydrogen production by methane decomposition is the types of catalysts used. Several researches analyze the improvement of catalysts' activity in order to achieve higher conversions of methane and longer life for catalysts. Catalytic systems containing $\mathrm{Ni}$ and $\mathrm{Fe}$ have been largely tested.

Abbas et al. (2009) reported that the rate of methane decomposition activity by transition metals presents the following order: $\mathrm{Co}, \mathrm{Ru}, \mathrm{Ni}$, $\mathrm{Rh}>\mathrm{Pt}, \mathrm{Re}, \mathrm{Ir}>\mathrm{Pd}, \mathrm{Cu}, \mathrm{W}, \mathrm{Fe}, \mathrm{Mo}$. However, Ermakova et al. (1999) have found that $\mathrm{Ni}$ or $\mathrm{Ni} /$ alumina and Fe/alumina showed the highest activity rates.

Ogihara et al. (2006) reported that a typical $40 \% \mathrm{Ni} / \mathrm{SiO}_{2}$ catalyst with a nickel-particle measuring 60-100 nm could produce carbon, around $491 \mathrm{~g}_{\mathrm{C}} / \mathrm{g}_{\mathrm{Ni}}$, during methane decomposition at $500^{\circ} \mathrm{C}$.

Using a commercial Ni-based catalyst, Suelves et al. (2005) reported that the concentration of hydrogen was around $80 \%$ at $700^{\circ} \mathrm{C}$, which corresponds to a rate of methane conversion close to the equilibrium rate established in theory.

The application of alloys as catalysts opens interesting routes to increase the production of hydrogen in methane decomposition. In addition, the introduction of a second metal as catalyst may provide significant changes in activity and selectivity. According to some publications, $\mathrm{Ni}-\mathrm{Cu}-\mathrm{Al}_{2} \mathrm{O}_{3}$ catalysts, prepared with co-precipitation methods, are more stable for methane decomposition than $\mathrm{Ni}-\mathrm{Al}_{2} \mathrm{O}_{3}$ catalysts.

Nuernberg et al. (2008) investigated the influence of operating conditions on the catalytic performance of $\mathrm{Co}$ supported on $\mathrm{Al}_{2} \mathrm{O}_{3}$. The authors studied the effect of different Co contents at a temperature range of $600-800^{\circ} \mathrm{C}$ and different methane partial pressures. It was found that the best conditions for hydrogen production by methane decomposition were at $800^{\circ} \mathrm{C}$ with a nitrogen-methane molar ratio of $6: 1$ and a $\mathrm{Co}$ loading of $20 \mathrm{wt} \%$.

Abbas et al. (2010) discussed catalysts that are used in several studies for catalytic methane decomposition using metals and carbonaceous catalysts. Muradov and Veziroglu (2008) also reported about carbon-neutral technologies that can be used in the production of hydrogen from fossil energy sources. The authors discussed the advantages of using carbon-based catalysts for methane decomposition.

The results of the experimental research conducted in our RECAT/UFF Laboratory using $\mathrm{Co} / \mathrm{SiO}_{2}$ catalysts for methane decomposition are presented below. 


\section{CATALYTIC TESTS FOR HYDROGEN PRODUCTION FROM METHANE DECOMPOSITION}

\subsection{THE EXPERIMENT}

We used catalysts with $10 \%$ of $\mathrm{Co} / \gamma-\mathrm{Al}_{2} \mathrm{O}_{3}$ and $10 \%$ and $20 \%$ of $\mathrm{Co} / \mathrm{SiO}_{2}$ prepared by incipient wetness method using $\mathrm{Co}\left(\mathrm{NO}_{3}\right)_{2} \cdot 6 \mathrm{H}_{2} \mathrm{O}$, according to the methodology presented in Guarino (2005).

The catalytic tests were carried out using a conventional fixed bed quartz reactor coupled with on line gas chromatograph. Methane conversion was calculated based on the outlet methane concentration. A mass of $200-400 \mathrm{mg}$ of catalysts was first dried with helium at $150^{\circ} \mathrm{C}$ for $30 \mathrm{~min}$. The catalyst was then reduced with hydrogen $(100 \mathrm{ml} / \mathrm{min})$ at $500^{\circ} \mathrm{C}$ for two hours. Methane decomposition happened through the contact between methane $\left(20 \%, 40 \%\right.$ or $60 \% \mathrm{CH}_{4}$ in helium) and the catalyst at $450^{\circ} \mathrm{C}$ or $500^{\circ} \mathrm{C}$. The total gas flow rate was $100 \mathrm{ml} / \mathrm{min}$ and was measured by a digital flow meter.

The temperature programmed reaction with water vapor was performed in a multipurpose unit coupled to a Balzers Omnistar quadrupole mass spectrometer. These experiments were conducted in order to evaluate the reactivity of carbon species produced on catalyst surface during methane decomposition reaction. The samples (the deactivated catalysts) were previously dried at $150^{\circ} \mathrm{C}$ for $30 \mathrm{~min}$ with $\mathrm{He}$ flow $(30 \mathrm{ml} / \mathrm{min})$ and heated with a mixture containing $\mathrm{H}_{2} \mathrm{O} / \mathrm{He}$ under passing $80 \mathrm{ml} / \mathrm{min}$ of $\mathrm{He}$ through a saturator with water at $54^{\circ} \mathrm{C}$. The temperature was raised to $1000^{\circ} \mathrm{C}$ at a heating rate of $10^{\circ} \mathrm{C} / \mathrm{min}$.

\subsection{RESULTS}

The catalysts activities are shown in Figures 4 and 5. Results indicate better stability for both catalysts when the reaction was performed at $450^{\circ} \mathrm{C}$ instead of at $500^{\circ} \mathrm{C}$; however, $\mathrm{Co} / \mathrm{Al}_{2} \mathrm{O}_{3}$ activity was lower than $\mathrm{Co} / \mathrm{SiO}_{2}$ activity. On the other hand, the reaction performed at $500^{\circ} \mathrm{C}$ showed quick deactivation, although it promotes higher conversions than those observed at $450^{\circ} \mathrm{C}$. $\mathrm{Co} / \mathrm{SiO}_{2}$ catalysts were more stable. Two processes of deactivation might contributed for that result: the first is related to the formation of carbon de- posits on the catalytic surface, which increases in reactions performed at $500^{\circ} \mathrm{C}$; the second is related to a sinterization process. The first process seems to contribute more effectively.

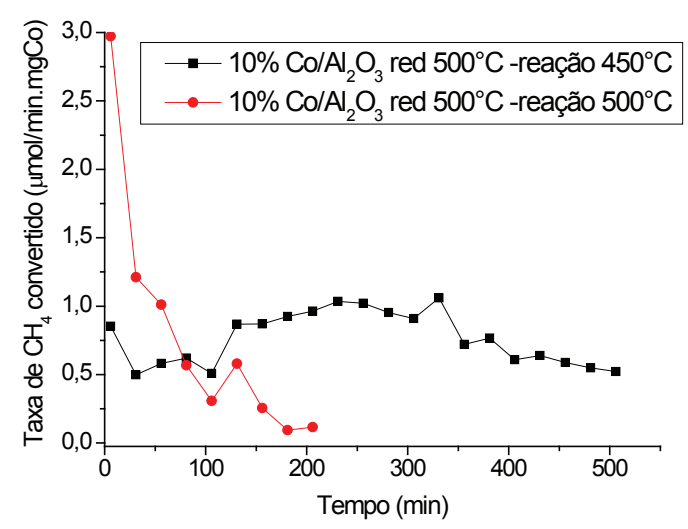

Figure 4 - Methane conversion rate for $10 \%$ $\mathrm{Co} / \mathrm{Al}_{2} \mathrm{O}_{3}$ catalyst reduced at $500^{\circ} \mathrm{C}$. Reaction at $450^{\circ} \mathrm{C}\left(\mathrm{m}_{\text {cat }}=299 \mathrm{mg}\right)$ and $500^{\circ} \mathrm{C}\left(\mathrm{m}_{\mathrm{cat}}=230 \mathrm{mg}\right)$

(Covre, 2009)

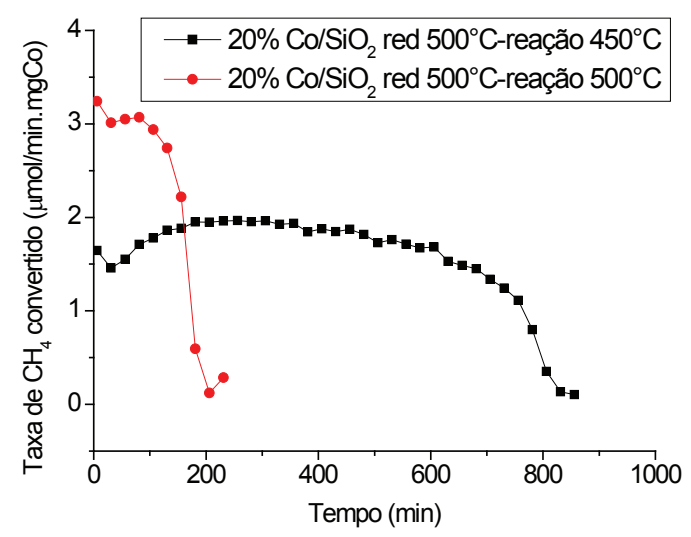

Figure 5 - Methane conversion rate for 20\% $\mathrm{Co} / \mathrm{SiO}_{2}$ catalyst reduced at $500^{\circ} \mathrm{C}$. Reaction at $450^{\circ} \mathrm{C}\left(\mathrm{m}_{\mathrm{cat}}=349 \mathrm{mg}\right)$ and $500^{\circ} \mathrm{C}\left(\mathrm{m}_{\mathrm{cat}}=233 \mathrm{mg}\right)$

(Covre, 2009)

Different compositions of methane in reactant mixture were tested for the reaction performed at $450^{\circ} \mathrm{C}$. Figure 6 shows the reaction rates for $20 \%, 40 \%$ and $60 \%$ of $\mathrm{CH}_{4} / \mathrm{He}\left(\mathrm{x}_{\mathrm{CH} 4}=0,2\right.$; $\mathrm{x}_{\mathrm{CH} 4}=0,4$ and $\mathrm{x}_{\mathrm{CH} 4}=0,6$, respectively). Results indicate that methane composition influenced the reaction rates and the deactivation process, which increased according to methane content. These results could be explained by the formation of carbon deposits on catalytic surface with metal particle encapsulated. 


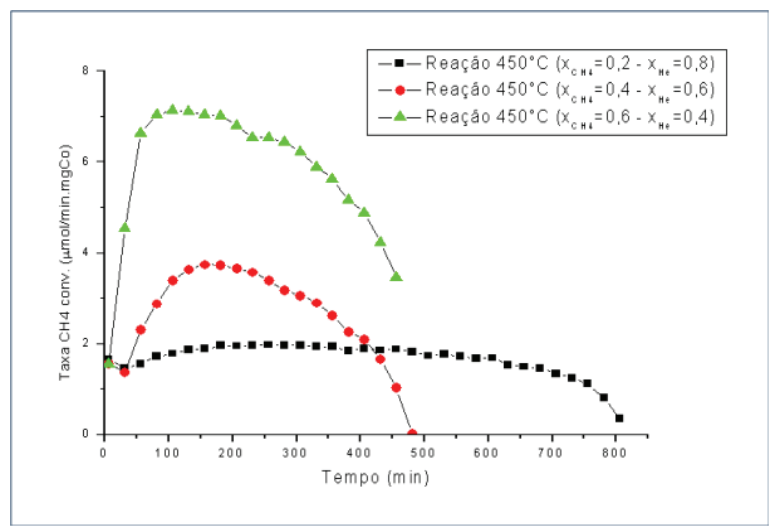

Figure 6 - Methane conversion rate at $450^{\circ} \mathrm{C}$ for $20 \% \mathrm{Co} / \mathrm{SiO}_{2}$ catalyst using different methane composition: $\mathrm{x}_{\mathrm{CH} 4}=0,2\left(\mathrm{~m}_{\mathrm{cat}}=349 \mathrm{mg}\right) ; \mathrm{x}_{\mathrm{CH} 4}=0,4$ $\left(\mathrm{m}_{\mathrm{cat}}=230 \mathrm{mg}\right)$ and $\mathrm{x}_{\mathrm{CH} 4}=0,6\left(\mathrm{~m}_{\mathrm{cat}}=231 \mathrm{mg}\right)$ (Covre, 2009)

However, we expected that $60 \%$ of methane would provide quicker deactivation. Villacampa et al. (2003) describes that, for $\mathrm{Ni} / \mathrm{Al}_{2} \mathrm{O}_{3}$ catalysts, the presence of hydrogen would prevent the formation of carbon encapsulated without decreasing the reaction rate for hydrogen production. The results obtained in the present work could be explained by the increased formation of hydrogen with higher contents of methane. This suggests that the use of natural gas with high amounts of methane could decrease the catalytic deactivation, enabling the process.

In a preliminary test carried out at RECAT/ UFF laboratory in order to evaluate the regeneration of $\mathrm{Co} / \mathrm{SiO}_{2}$ catalysts, Covre et al. (2009 a, b) observed that, after reactivation with water vapor, the catalytic activity was restored to $4,41 \mu \mathrm{mol} /$ $\left(\mathrm{min} . \mathrm{mg}_{\mathrm{Co}_{\mathrm{O}}}\right)$, around the same value obtained in the initial reaction $-4,36 \mu \mathrm{mol} /\left(\mathrm{min}_{\mathrm{mg}} \mathrm{mg}_{\mathrm{Co}}\right)$; it is important to point out that the regeneration test occurred for only one hour.

Figure 7 shows the reactivity with water vapor, as a function of the temperature, of carbon deposits formed on $20 \% \mathrm{Co} / \mathrm{SiO}_{2}$ catalysts after methane decomposition at $450^{\circ} \mathrm{C}$. We have observed $\mathrm{CO}$ and $\mathrm{H}_{2}$ production beginning at $500-600^{\circ} \mathrm{C}$, as well as the production of small quantities of $\mathrm{CO}_{2}$. These results suggest that the formation of synthesis gas from the regeneration of catalysts could also enable methanol production through an integrated process of $\mathrm{H}_{2}$ and methanol synthesis.

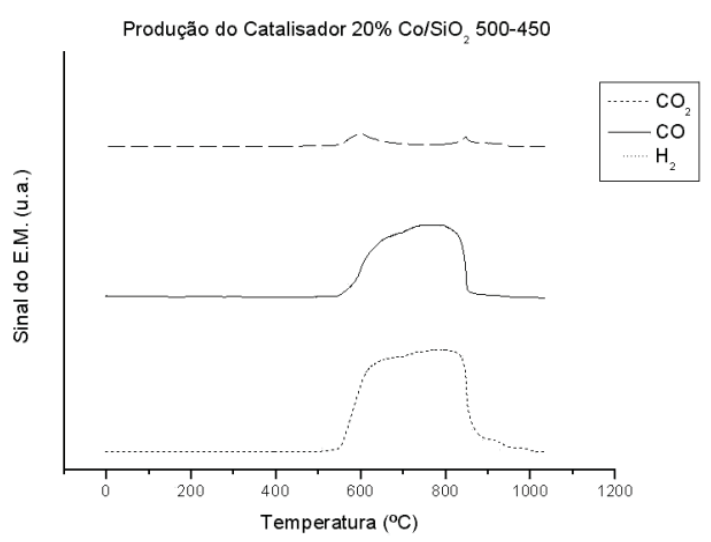

Figure 7 - Carbon deposits formed on the surface of $20 \% \mathrm{Co} / \mathrm{SiO}_{2}$ catalyst after methane decomposition at $450^{\circ} \mathrm{C}$. Temperature programmed with water vapor (Silva et al., 2010)

\section{CONCLUSIONS}

The present work focused on the importance of using hydrogen as an attractive alternative to conventional fuels due to its environmentally friendly use.

We have presented the current processes employed for the production of hydrogen from natural gas: steam reforming of methane, partial oxidation, and auto-thermal reforming. The main issue discussed was that such processes generate a great production of $\mathrm{CO}_{2}$, released in the environment by factories.

A promising alternative for the production of pure hydrogen without contaminated gases based on the direct catalytic decomposition of methane were proposed.

Results of methane decomposition reaction at $450^{\circ} \mathrm{C}$ and $500^{\circ} \mathrm{C}$ using $\mathrm{Co} / \mathrm{SiO}_{2}$ and $\mathrm{Co} /$ $\mathrm{Al}_{2} \mathrm{O}_{3}$ reduced at $500^{\circ} \mathrm{C}$ were presented.

The rate of methane conversion at $450^{\circ} \mathrm{C}$ proved to be stable. However, when methane decomposition occurred at $500^{\circ} \mathrm{C}$, the deactivation of catalysts was observed. Even though, after regeneration with water vapor, $20 \%$ of $\mathrm{Co} / \mathrm{SiO}_{2}$ catalysts restored its initial activity.

It was possible to evaluate the formation of $\mathrm{CO}, \mathrm{H}_{2}$, and small quantities of $\mathrm{CO}_{2}$ during the regeneration reaction.

These results suggest that the process of hydrogen production with continuous regeneration of the catalyst can be a promising alternative. 


\section{BIBLIOGRAPHICAL REFERENCES}

ABBAS, H. F., DAUD, W. M. A. W. (2010) “Нydrogen production by methane decomposition: A review". International Journal of Hydrogen Energy, 35. 1160-1190.

AVDEEVA L.B.; KOCHUBEY D. I.; SHAIKHUTDINOV S.K. (1999) "Cobalt Catalysts of Methane Decomposition: Accumulation of the Filamentous Carbon". Applied Catalysis, 177, 43.

BOSKOVIC, G.; SMITH, K. J. (1997) "Methane Homologation and Reactivity of Carbon Species on Supported Co Catalysts". Catalysis Today, vol.37, p. 25.

COVRE, J. P. M., PASSOS, F. B., SILVA, R. R. C. M. (2009). "Estudo de Desativação e Regeneração dos Catalisadores de $\mathrm{Co} / \mathrm{SiO}_{2}$ na Decomposição do Metano para Geração de Hidrogênio". In Anais do $15^{\circ}$ Congresso Brasileiro de catálise, CDROM, Armação dos Búzios, RJ.

DOURADO J. C. C.; OLIVEIRA B. T. M.; ROCHA FILHO, N. S.;PASSOS, F. B.; SILVA, R. R. C. M. (2007). "Geração de Hidrogênio a partir da Decomposição do Metano em Catalisadores a Base de Cobalto". In: Anais do $14^{\circ}$ Congresso Brasileiro de Catálise, Porto de Galinhas, CDROM, Porto de Galinhas, PE.

ERMAKOVA, M. A.; ERMAKOV, D. Y.; KUVSHINOV, G. G. Applied Catalysis, A, vol. 201, p. 61, 2000.

FERREIRA-APARÍCIO, P.; GUERRERORUIZ, A.; RODRIGUEZ-RAMOS, I. (1997). "Methane Interaction with Sílica and Alumina Supported Metal Catalysts". Applied Catalysis A: General, vol. 148, p. 343.

GUARINO, A. P. F. (2005) "Decomposição do Metano em Catalisadores $\mathrm{Co} / \mathrm{SiO}_{2}, \mathrm{Co} / \mathrm{Al}_{2} \mathrm{O}_{3} \mathrm{e}$ $\mathrm{Co} / \mathrm{Nb}_{2} \mathrm{O}_{5}$ ". Tese de Mestrado, Universidade Federal Fluminense. Niterói, RJ.

GUARINO, A. P. F., THOMAZELLI, B.M.O. PASSOS, F. B., SILVA, R. R. C. M. (2005). "O efeito do suporte em catalisadores $\mathrm{Co} / \mathrm{SiO}_{2}$,
$\mathrm{Co} / \mathrm{Al}_{2} \mathrm{O}_{3}$ e $\mathrm{Co} / \mathrm{Nb}_{2} \mathrm{O}_{5}$ na decomposição do metano". In: $13^{\circ}$ Congresso Brasileiro de Catálise, CDROM.

MURADOV, N.Z.; CHEN, Z.; SMITH, F. (2005). "Fossil Hydrogen with reduced $\mathrm{CO}_{2}$ emission: Modeling termocatalytic decomposition of methane in a fluidizes bed of carbon particles". International Journal of Hydrogen Energy, vol. 30, P. 225-237.

MURADOV, N.Z.; VEZIROGLU, T. N. (2008). "Green path from fossil-based to hydrogen economy: An overwiew of carbon-neutral technologies". International Journal of Hydrogen Energy, 33, p. 6804-6839.

NUERNBERG, G. B., FAJARDO, H. V., MEZALIRA, D. Z., CASARIN, T. J., PROBST, L.F.D., CARRENO, N.L.V. (2008). "Preparantion and eavluation of $\mathrm{Co} / \mathrm{Al}_{2} \mathrm{O}_{3}$ catalysts in the production of hydrogen from thermocatalytic decomposition of methane: influence of operating conditions on catalyst performance". Fuel. 87 (89), 1698-1704.

OGIHARA, H.; TAKENAKA, S.; YAMANAKA, I.; TANABE, E.; GENSEKI, A.; OTSUDA, K. (2006). "Formation of Highly Concentrated Hydrogen through Methane decomposition over Pd-bases Alloy Catalysts". Journal of Catalysis, vol. 238, p. 353.

SILVA, G. C., PASSOS, F. B, SILVA, R. R. C. M., (2008). "Estudo de um Processo de Decomposição de Metano para Geração de Hidrogênio". In: XVII Congresso Brasileiro de Engenharia Quimica, Recife.

SILVA, R. R. C. M., Oliveira, B. T. M., Guarino, A. C. P. F., Passos, F. B. (2008). "Decomposição do Metano em Catalisadores de Cobalto Suportados - O Efeito das Propriedades Texturais na Atividade Catalítica para Formação de Carbono Filamentar”. Revista Engevista, 10 (2) 91-99.

SOLYMOSI, F.; ERDOHELYI, A.; CSERÉNYI, J.; FELVÉGI, A. (1994). "Activation of CH4 and Its Reaction with CO2 over Supported Rh Catalysts”. Journal of Catalysis, vol. 147, p. 272. 
SUELVES, I., LÁZARO, M.J., MOLINER, R., CORBELLA, B. M., PALACIOS, J. M. (2005). "Hydrogen production by thermocatalytic decomposition of methane on $\mathrm{Ni}$-based catalysts: influence of operating conditions on catalyst deactivation and carbon characteristics". International Journal of Hydrogen Energy, 30 (15), 1555-1567.
VILLACAMPA, J.I.; ROYO, C.; ROMEO, E.; MONTOYA, J.A. (2003). Applied Catalysis A: General, 252, p. 363.

http://www.revistafator.com.br (2010) "Produção de óleo no Brasil aumenta em 6\%". Available at: Accessed in sep. 17, 2010. 